\section{Road to the Civil War: The Missouri Compromise}

\section{Julius Nathan Fortaleza Klinger \\ Junior, History and Secondary Education}

"The lack of an ability to compromise led to the Civil War." This blunt statement came from the White House Chief of Staff John F. Kelly, who was featured in an interview in October 2017 on Laura Ingraham's television show, The Ingraham Angle. ${ }^{1}$ Essentially, he claimed that for the eighty-four years spanning from the thirteen colonies' declaration of independence from Britain to the onset of the Civil War, the United States government failed to pass any compromises that would have avoided the bloody conflict that pitted North against South.

Kelly's statement is misleading, because the entire existence of the constitutional United States up until the war was filled with compromises. Each of these documents were either wholly focused on or had a section devoted to dealing with the main cause of the Civil War: the enslavement of Africans in the US. Well-known examples of these agreements include the Constitution's Three-Fifths Compromise (1789), the Missouri Compromise (1820), and the last successfully-passed major compromise, the Kansas-Nebraska Act (1854). Therefore, Chief of Staff Kelly was incorrect in stating that the government failed to make compromises, as the existence of the documents previously listed immediately refutes his claim.

However, it was those same compromises that, in the end, failed to stop the Civil War from happening. Thus, it was not the lack of an ability to compromise that led to war, but was instead the lack of an ability to make compromises that involved long-term solutions to the question of slavery. An implication of this is that many of the compromises leading up the Civil War were simply stopgaps, rather than true solutions. The first example of this is the Missouri Compromise of 1820. It was the first major compromise to dictate whether new states entering the Union would allow or prohibit slavery. Although deemed a compromise at the time and remembered as such, the Missouri Compromise established the foundation of the sectional disagreement between the North and South that ultimately led to the Civil War.

The compromise itself came about as a response to the debates over what Missouri's policy on slavery would be when it applied for statehood. Illinois senator Jesse B. Thomas added the compromise proviso to the legislation, which dictated that all states that entered the Union from then on would permit slavery if geographically located beneath the $36^{\circ} 30^{\prime}$ parallel of latitude, and would prohibit slavery if north of that line. Missouri itself was an exception to that latitude-based rule, and Maine joined the Union as a free state in accordance with maintaining the balance between northern free states and slaveholding southern states. It was signed 
into law by president James Monroe on March 6, 1820. ${ }^{2}$

The bill, however, did not pass through Congress and directly to Monroe's desk. The Missouri Territory first applied to become a state in 1817, and Congress debated over the authorization of that application from early 1819-1820. As Dr. Robert Pierce Forbes describes it in The Missouri Compromise and Its Aftermath: Slavery and the Meaning of America, "the debate over the terms over Missouri's admission to the Union, and by extension, the future of slavery in the unsettled American continent, would throw the nation into its greatest political crisis between the Revolution and the Civil War."3

Early in the debate over Missouri's statehood, on February 13, 1819, Democratic-Republican representative James Tallmadge of New York introduced an amendment to the bill that prohibited "the further introduction of slavery or involuntary servitude," and that all children of slaves born in Missouri after it attained statehood were to be freed at the age of 25 . Southern members of Congress opposed the bill, while northern members approved of it, and this disagreement led to weeks of debate. Tallmadge's friend and fellow New Yorker, John Taylor, framed the debate as one that would have long-term effects on the United States as it eventually expanded to stretch from coast to coast. He further stated that Congress did indeed have the right and power to prohibit slavery in new states, as Congress had already wholly banned the practice northwest of the Ohio River with the Northwest Ordinance, placed limitations on the states of Illinois and Indiana, and established conditions in Orleans Territory. Taylor concluded with the statement that slavery was evil, but could be easily eradicated. While his impassioned speech to Congress painted a hopeful outlook on the conclusion of the debate, Forbes states that "Taylor's astounding assertion... showed the extent of northern inattention to the growth of the institution." 4

This attitude was not only common for northern politicians however, but also northern citizens. Timothy Fuller, a representative from Massachusetts, gave his own impassioned speech to congress about the Tallmadge amendment. The National Register, a weekly newspaper, transcribed in full Fuller's speech. In it, he advocates his support for the amendment, asserting that it is in line with Republican values and that equality for all people is ensured by the Declaration of Independence itself. ${ }^{5}$ It was this speech that finally caused overt sectionalism regarding slavery to emerge.

Southern congressman instantly rose up in disagreement with Fuller, as "most slaveholders quickly recognized that perhaps nothing could endanger their 'rights' to their slaves more fundamentally than discussion of the Declaration of Independence and 'republican principles." In fact, Virginia congressman Edward Colston went so far as to charge Fuller with criminality for asserting the natural rights of black slaves in America.

Most telling of all, however, was the charge that Virginia congressman Thomas Cobb leveled at Tallmadge. Potentially in reference to the violent and successful 
Haitian Revolution of 1791-1804 that saw black slaves in French-controlled Saint-Domingue overthrow their white French lords, Cobb prophetically claimed that the Union would be destroyed if Tallmadge's amendment passed, and that Tallmadge had "kindled a flame which all the waters of the ocean cannot put out, which seas of blood can only extinguish." Cobb would be proven correct, but it would not be the blood shed from a country-wide slave rebellion, and instead be the blood of the biggest and bloodiest war ever fought on US soil.

In the end, the Committee of the Whole passed the amendment by a vote of 79 for to 67 against. John Scott, Missouri's non-voting representative, railed against the amendment as an unconstitutional inhibition on the rights of Missourians. Other southerners, such as Edward Colston, defended the rights of Missourians as well. Tallmadge himself entered the debate for the first time to defend his amendment, and was shocked by the vehemence of southern opposition. Incited, Tallmadge's response clearly defined the direction of the path upon which these debates had set the country upon: "If a Dissolution of the Union must take place, let it be so! If civil war, which gentlemen so much threaten, must come, I can only say, let it come!"? In line with what Thomas Cobb had prophesied earlier, Tallmadge called for a civil war three-decades before it actually happened in order to decide the fate of slavery in the US once and for all.

The solution to these debates was originally proposed by Taylor; the line of demarcation at the $36^{\circ} 30^{\prime}$ parallel. However, southerners initially rejected the proposal outright because it would have been a northern, antislavery victory. This was followed by the adjournment of that Congress, who would not meet again until December. In the meantime, antislavery sentiments grew in the North, with numerous newspapers publishing Democratic-Republican letters of anguish over the southern defense of slavery. ${ }^{8}$ During that adjournment, slaveholding southerners exhibited their own discontent with the antislavery sentiments of the north when a mob of slaveholders beat and whipped a New Jersey immigrant who had publicly proclaimed his opposition to slavery. ${ }^{9}$ When the Sixteenth Congress met that December, the debate over Missouri heated up once again.

With Maine's application for statehood in 1819, Speaker of the House and supporter of slavery - Henry Clay saw this as an opportunity to save Missouri's right to allow slavery. He was one of the key architects who linked Maine's entrance to the Union to that of Missouri's, his reasoning being that Missouri would then allow slavery while Maine prohibited it, thus maintaining the balance of power. After some lengthy debate and outcry from Maine's representative, the linkage of Missouri's and Maine's statehood applications passed. ${ }^{10}$ Finally, the Missouri question was answered, with Missouri joining the Union as a slaveholding state and Maine as a free state. A part of this legislation was the establishment of the exact same line of demarcation dividing the 
free North from the slavery South proposed by John Taylor, but this time by pro-slavery congressman Jesse Thomas. In the end, the balance had been maintained, a line that divided the country had been drawn, and it appeared that the debate over slavery had been settled.

After the Compromise passed in March 1820, Thomas Jefferson himself relayed his personal thoughts and feelings on the matter to former Maine representative John Holmes. ${ }^{11}$ In his letter dated April 22, 1820 , Jefferson says of the compromise: But this momentous question, like a fire bell in the night, awakened and filled me with terror. I considered it at once as the knell of the Union. it is hushed indeed for the moment. but this is a reprieve only, not a final sentence. a geographical line, coinciding with a marked principle, moral and political, once conceived and held up to the angry passions of men, will never be obliterated; and every new irritation will mark it deeper and deeper.

Most obvious in this portion of the letter is Jefferson's disapproval of the compromise. Just as Thomas Cobb had during the Fifteenth Congress, Jefferson predicted that the line dividing the North from the South would only serve to deepen sectional rivalries, and thus that a massive conflict was now unavoidable.

Eventually this sectional division and debate over slavery would indeed come to a head. The Kansas-Nebraska Act of 1854 repealed the Missouri Compromise entirely, and allowed for the Kansas and Nebraska territories to self-determine by vote whether they would join the Union as free or slave states. This not only overturned the 1820 line of demarcation, but also caused a violent crisis to erupt in Kansas, known as Bleeding Kansas. Pro- and antislavery supporters clashed in the Kansas Territory, with widespread violence and murder. This bloody conflict - only six short years before the fated election of Abraham Lincoln presaged the Civil War that Thomas Cobb had prophesied three decades before. Ultimately, the debates over Missouri's statehood that had turned to debates over slavery itself and the subsequent compromise that established a legal line dividing the North and South forced America to constantly confront the problem of slavery until the only answer was war. 


\section{NOTES}

${ }^{1}$ Eli Rosenberg and Cleve R. Wootson Jr., "John Kelly calls Robert E. Lee an 'honorable man' and says 'lack of compromise' caused the Civil War" last modified October 31, 2017.

https:/www.washingtonpost.com/news/morning-mix/wp/2017/10/31/john-kelly-calls-robert-e-lee-an-honorable-ma n-and-says-lack-of-compromise-caused-the-civil-war/?utm term=.62a13950ddd3

2 "Acts of the Sixteenth Congress of the United States." A Century of Lawmaking for a New Nation: U.S. Congressional Documents and Debates, $1774-1875.16^{\text {th }}$ Congress, $1^{\text {st }}$ Session. pg. 545. From Library of Congress, A Century of Lawmaking for a New Nation: U.S. Congressional Documents and Debates, 1774-1875. https://memory.loc.gov/cgi-bin/ampage?collId=llsl\&fileName=003/lls1003.db\&recNum=586 (accessed December 12, 2017).

${ }^{3}$ Robert Pierce Forbes, The Missouri Compromise and Its Aftermath: Slavery and the Meaning of America (North Carolina: University of North Carolina Press, 2007), 33.

${ }^{4}$ Forbes. Missouri Compromise and Its Aftermath. 37-38.

${ }^{5}$ Missouri question. (1820, May 06). The National Register, a Weekly Paper, Containing a Series of the Important Public Documents, and the Proceedings of Congress; Statistical Tables, Reports and Essays, Original and Selected, upon Agriculture, Manufactures, Commerce, and Finance; (TRUNCATED) Retrieved from

https://search-proquest-com.libproxy.temple.edu/docview/127669455?accountid=14270

${ }^{6}$ Forbes. Missouri Compromise and its Aftermath. 39.

${ }^{7}$ Forbes. Missouri Compromise and its Aftermath. 43.

${ }^{8}$ Forbes. Missouri Compromise and its Aftermath. 65.

${ }^{9}$ Forbes. Missouri Compromise and its Aftermath. 54.

${ }^{10}$ Forbes. Missouri Compromise and its Aftermath. 79.

${ }^{11}$ Paul Finkelman, Millard Fillmore: The American Presidents Series: The $13^{\text {th }}$ President, 1850-1853 (New York: Henry Holt and Company, 2011), 38-39. 